\title{
Quantification of gamma-secretase modulation differentiates inhibitor compound selectivity between two substrates Notch and amyloid precursor protein
}

\author{
Ting Yang, Dilyara Arslanova, Yongli Gu, Corinne Augelli-Szafran and \\ Weiming Xia*
}

Address: Center for Neurologic Diseases, Department of Neurology, Brigham and Women's Hospital, Harvard Medical School, Harvard University, Boston, MA, USA

Email: Ting Yang - tyang3@partners.org; Dilyara Arslanova - arslanov@post.harvard.edu; Yongli Gu - ygu@partners.org; Corinne Augelli-

Szafran - caugelli@rics.bwh.harvard.edu; Weiming Xia* - wxia@rics.bwh.harvard.edu

* Corresponding author

Published: 4 November 2008

Molecular Brain 2008, I:15 doi:10.1186/I756-6606-I-15

This article is available from: http://www.molecularbrain.com/content///I/I5

(C) 2008 Yang et al; licensee BioMed Central Ltd.

This is an Open Access article distributed under the terms of the Creative Commons Attribution License (http://creativecommons.org/licenses/by/2.0), which permits unrestricted use, distribution, and reproduction in any medium, provided the original work is properly cited.

\begin{abstract}
Background: Deposition of amyloid- $\beta$ protein $(A \beta)$ is a major pathological hallmark of Alzheimer's disease (AD). $A \beta$ is generated from $\gamma$-secretase cleavage of amyloid precursor protein (APP). In addition to APP, $\gamma$-secretase also cleaves other type I integral membrane proteins, including the Notch receptor, a key molecule involved in embryonic development.

Results: To explore selective $\gamma$-secretase inhibitors, a combination of five methods was used to systematically determine these inhibitors' profiles on the $\gamma$-secretase cleavage of APP and Notch. When two potent $\gamma$-secretase inhibitors, compound E (cpd E) and DAPT, were used in a conventional in vitro $\gamma$-secretase activity assay, cpd $E$ completely blocked $A \beta$ generation from the cleavage of substrate APP Cl00, but only had a minor effect on Notch cleavage and NICD generation. Next, cpd E and DAPT were applied to HEK293 cells expressing a truncated Notch substrate Notch $\triangle E$. Both cpd $E$ and DAPT were more potent in blocking A $\beta$ generation than NICD generation. Third, a reporter construct was created that carried the NICD targeting promoter with three $\mathrm{Su}(\mathrm{H})$ binding sequences followed by the luciferase gene. We found that the inhibition of NICD generation by cpd E and DAPT was consistent with the reduced expression of luciferase gene driven by this Notch targeting promoter. Fourth, levels of "Notch-A $\beta$-like" (N $\left.\beta^{*}\right)$ peptide derived from two previously reported chimeric APP with its transmembrane domain or the juxtamembrane portion replaced by the Notch sequence were quantified. Measurement of $N \beta^{*}$ peptides by ELISA confirmed that $\mathrm{EC}_{50}$ 's of cpd $\mathrm{E}$ were much higher for $\mathrm{N} \beta^{*}$ than $\mathrm{A} \beta$. Finally, the expression levels of Notch target gene her6 in cpd E or DAPT-treated zebrafish were correlated with the degree of tail curvature due to defective somitogenesis, a well characterized Notch phenotype in zebrafish.
\end{abstract}

Conclusion: Our ELISA-based quantification of $A \beta$ and $N \beta^{*}$ in combination with the test in zebrafish provides a novel approach for efficient cell-based screening and in vivo validation of APP selective $\gamma$-secretase inhibitors. 


\section{Background}

Genetic and neuropathologic evidence suggests that Alzheimer's disease (AD) is caused partly by the overproduction and lack of clearance of the amyloid $\beta$ peptide (A $\beta$ ) [1]. This $A \beta$ peptide is generated by sequential cleavages of the amyloid precursor protein (APP) by $\beta$-secretase, which generates a $12 \mathrm{kDa}$ C-terminal stub of APP (C99), and by $\gamma$-secretase to yield two major species of $A \beta$ that end at residue $40\left(\mathrm{~A} \beta_{40}\right)$ or $42\left(\mathrm{~A} \beta_{42}\right)$ [2,3]. In addition to cleaving APP, $\gamma$-secretase also mediates the final proteolytic cleavage of the Notch receptor $[4,5]$. Notch signaling is critical to a wide variety of cell fate determinations during embryonic development as well as throughout adulthood. After ectodomain shedding, the remaining membrane-bound C-terminal stub is cleaved by $\gamma$-secretase to release the Notch-1- $\beta$ peptide $(\mathrm{N} \beta$, similar to amyloid $\beta$ peptide from APP) and the Notch IntraCellular Domain (NICD). NICD is subsequently translocated to the nucleus where it regulates gene expression [5-7].

There are about $50 \gamma$-secretase substrates in addition to APP and Notch that include DCC [8], ErbB-4 [9,10], Eand N-cadherin [11,12], CD44 [13,14], LRP [15], Nectin $1 \alpha$ [16], Delta and Jagged [17], Glutamate Receptor Subunit 3 [18], APLP1 and APLP2 [19-21], p75 Neurotrophin Receptor [22], Syndecan3 [23], Colony Stimulating factor-1 [24] and Interleukin-1 Receptor II [25]. All of these substrates are type I membrane proteins and have diverse functions, including transcriptional regulation, cell-cell adhesion, regulation of ion conductance, and neurotrophin signaling. The cleavage of these proteins can be blocked by reported $\gamma$-secretase inhibitors and are fully dependent on each $\gamma$-secretase component [26].

$\gamma$-Secretase is composed of presenilin 1 (PS1), anterior pharynx defective-1 (Aph-1), presenilin enhancer-2 (Pen2 ), and nicastrin (Nct). PS1 carries the catalytic site of $\gamma$ secretase, as we have demonstrated that a mutation of two critical aspartate (Asp) residues abrogates enzymatic activity [27]. Nicastrin is required for $\gamma$-secretase activity [28$35]$ and is an important component in the complex, possibly functioning as the receptor for different substrates [36]. Genetic screens further revealed the aph-1 gene and the pen-2 gene that encodes two essential components of the $\gamma$-secretase complex $[37,30,38]$; overexpression of all four components results in increased $\gamma$-secretase activity, both in mammalian cells [39-44] and in yeast [45].

Among all reported $\gamma$-secretase inhibitors, transition-state analogues prevent A $\beta$ generation and bind directly to PS1 and PS2 $[46,47]$. Most reported $\gamma$-secretase inhibitors specifically block the cleavage at both sites in APP and Notch without differentiating between the two substrates. It has been reported that a subset of NSAIDS (nonsteroidal antiinflammatory drugs) that include ibuprofen, indometh- acin and sulindac sulphide, specifically block the cleavage of the $\gamma$-secretase substrates at the middle of transmembrane domain (TMD) without affecting the generation of the intracellular domains (ICDs) of several type I transmembrane proteins that include APP, ErbB-4, and Notch [48]. These NSAIDs directly modulate $\gamma$-secretase complex and become a part of a new class of $\gamma$-secretase modulators [49-54]. Another $\gamma$-secretase modulator is Gleevec that has been approved for the treatment of chronic myeloid leukemia and gastrointestinal stromal tumors. In addition to Gleevec binding to Abelson leukemia (Abl) tyrosine kinase, it also was shown to selectively inhibit APP cleavage and $A \beta$ production without affecting Notch cleavage at the concentration of $10 \mu \mathrm{M}$ [55].

Two potent $\gamma$-secretase inhibitors, DAPT and compound E (cpd E), show a range of $\mathrm{IC}_{50}$ values in blocking $\gamma$-secretase activity in both in vitro and cell-based assays. For cpd E, the $\mathrm{IC}_{50}$ for NICD and $\mathrm{A} \beta$ generation in cultured cells was found as low as $1.7 \mathrm{nM}$ [56] and $0.3 \mathrm{nM}$ [57], respectively. De novo $A \beta$ and AICD generation in vitro was inhibited by DAPT with $\mathrm{IC}_{50}$ values ranging from 10-100 nM [58,59]. A direct comparison of NICD and AICD levels in an in vitro $\gamma$-secretase activity assay showed a partial inhibition of NICD generation by DAPT at $50 \mathrm{nM}$, and AICD at 100 $\mathrm{nM}$ [60]. Different assay systems were implemented in these various studies to measure the $\mathrm{IC}_{50}$ values of the $\gamma$ secretase inhibitors. Since there were a variety of assays used, it was difficult to compare the potency toward the cleavage of APP and Notch among different systems.

The current study combined five assay methods and systematically determined the pharmacological profile of cpd E and DAPT on $\gamma$-secretase cleavage of APP and Notch. This approach includes the measurements of the potency of $\gamma$-secretase inhibitors and their effect on the inhibition of the $\gamma$-secretase activity in vitro, NICD generation, NICD downstream transcription activation, cleavage of $\mathrm{APP} /$ Notch chimeric substrates, and Notch downstream target gene expression in zebrafish. Previous studies showed that treating zebrafish with DAPT at the late blastula stage caused defects in somitogenesis and neurogenesis [61]. Similarities have been observed between DAPT-treated embryos and previously reported zebrafish Notch pathway mutants like bea, des, aei, and wit [62,63]. The increased neurogenesis in DAPT-treated embryos can be reduced by microinjecting NICD mRNA. Interestingly, defective somitogenesis was not observed in zebrafish embryos that were treated with the A $\beta$-lowering JLK nonpeptidic isocoumarin inhibitors [64]. In this study, the expression levels of Notch target gene her 6 were correlated to the phenotypes that were observed in the embryos treated with DAPT and cpd E. This provided an in vivo system to test the effect of $\gamma$-secretase inhibitors on Notch signaling in a whole vertebrate animal. 


\section{Results \\ Low concentration of compound $E$ selectively blocks $A \beta$ production with minimum effect on NICD generation in vitro}

To characterize the direct effect of two $\gamma$-secretase inhibitors cpd E and DAPT on APP/Notch cleavage, a conventional in vitro $\gamma$-secretase assay to quantify their inhibitory potency was used $[58,65,66]$. The incubation of $\gamma$-secretase complex with purified substrates at $37^{\circ} \mathrm{C}$ for $4 \mathrm{hr}$ was followed by Western Blot (WB) to determine the quantity of newly generated NICD. A newly generated band that corresponds to the predicted size of the NICD-Flag was detected (Fig. 1A and 1B). A clear reduction of NICD gen- eration in samples containing DAPT (Fig. 1A) or cpd E (Fig. 1B) was found, and the reduction was dose dependent.

The same preparation of $\gamma$-secretase complex was mixed with C100Flag followed by ELISA to quantify the levels of newly generated $A \beta$. As expected, both DAPT (Fig. 1C) and cpd E (Fig. 1D) blocked $\gamma$-secretase cleavage of APP C100Flag and caused a dose-dependent reduction of $A \beta$ production.

Close comparison of the inhibition profile of cpd $\mathrm{E}$ and DAPT on $A \beta$ and NICD generation revealed a divergence
A

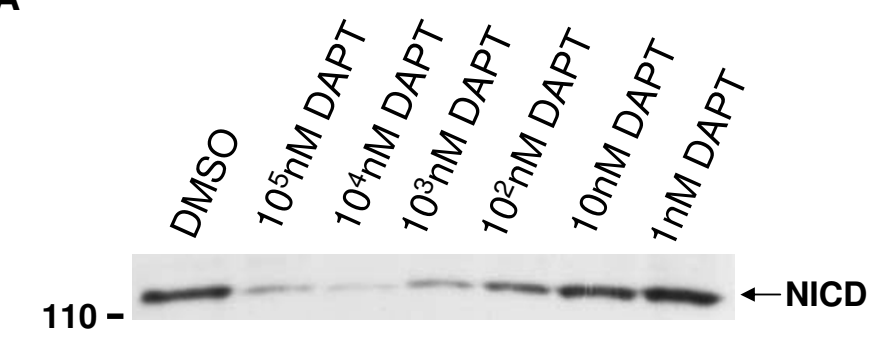

B

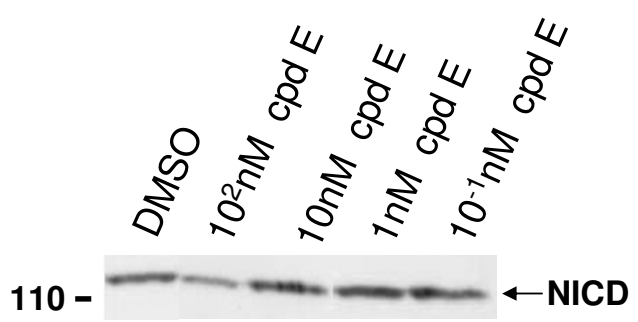

B
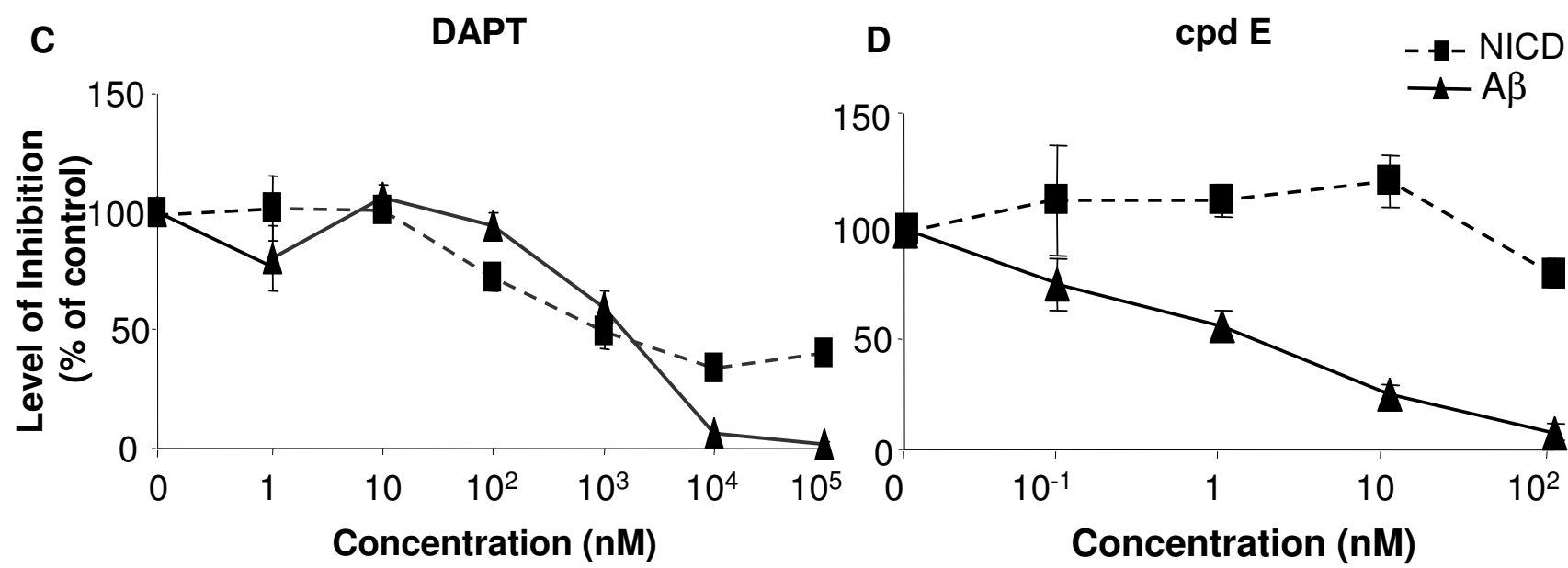

Figure I

Generation of NICD and A $\beta$ from purified APP and Notch substrate $C I 00$ and NI00 in an in vitro $\gamma$-secretase activity assay. The $E$. coli generated APP- and Notch-based, I00-residue $\gamma$-secretase substrates CI00-Flag and NI00-Flag were mixed with the membrane vesicles solubilized in CHAPSO after DMSO or compounds were added. The mixture was incubated at $37^{\circ} \mathrm{C}$ for 4 hours. A. A dose-dependent inhibition of NICD generation by DAPT. Generation of NICD was detected by Western blot (WB) with antibody 1744 specifically recognizing N-terminus of NICD. B. Generation of NICD was inhibited in the presence of $100 \mathrm{nM}$ of cpd E. C. Levels of NICD determined by WB were quantified by densitometry (dotted line). Levels of $A \beta$ generated from the $\gamma$-secretase cleavage of $\mathrm{Cl} 00$ in the presence of DAPT were determined by ELISA (solid line). Comparison of NICD and A $\beta$ generation in the presence of DAPT suggests that high concentrations of DAPT were more potent in blocking $A \beta$ than NICD generation. D. NICD (dotted line) and A $\beta$ (solid line) generation in the presence of cpd $E$ were compared. Cpd $E$ inhibited $A \beta$ generation with an $I_{50}$ of $I \mathrm{nM}$ and is more potent in inhibiting $A \beta$ than NICD. 
in their potencies. Low concentrations of DAPT did not show much difference in inhibiting NICD and $A \beta$ generation, but 10 and $100 \mu \mathrm{M}$ of DAPT blocked $\sim 60 \%$ of NICD generation compared to a complete depletion of $\mathrm{A} \beta$ production (Fig. 1C). While $100 \mathrm{nM}$ of cpd E could almost deplete any A $\beta$ generation from substrate APP C100, its effect on NICD was much less obvious (Fig. 1D). There was only minor reduction of NICD levels compared to DMSO controls. This led to the speculation that certain $\gamma$ secretase inhibitors may specifically inhibit APP at a particular range of doses that have minimum effect on Notch signaling.

\section{Compound $E$ and DAPT differentially inhibit $A \beta$ and NICD generation in cultured cells}

Since many compounds could behave differently in vitro versus in culture cells, cpd E and DAPT were tested in cultured cells (Fig. 2). HEK293 cells stably expressing Swedish mutant APP were transiently transfected with Notch $\Delta \mathrm{E}$, a truncated Notch construct that is readily cleaved by the $\gamma$-secretase to generate NICD for downstream signaling transduction [67]. Notch $\Delta$ E expressing cells were treated with increasing concentrations of DAPT or cpd E. Cell lysates were subjected to WB for measuring the generation of NICD (Fig. 2A), and conditioned media were collected for $\mathrm{A} \beta$ measurement by ELISA (Fig. 2B,C).

Semi-quantification of NICD levels was detected by WB, and the inhibition profile of DAPT (Fig. 2B) and cpd E (Fig. 2C) were compared on NICD and $A \beta$ generation in cultured cells. It was found that high doses of DAPT and cpd E could not completely eliminate NICD generation in cultured cells. This was in contrast to $A \beta$ levels that were efficiently reduced to almost undetectable levels. Since Notch signaling and levels of NICD can be examined by quantifying the expression of the Notch target gene, a Hes1 reporter construct (Hes-Luc) was generated by insertion of three $\mathrm{Su}(\mathrm{H})$ binding sequences in the pGL3-pro luciferase reporter vector. Hes-Luc and Notch $\Delta \mathrm{E}$ were transiently transfected into HEK293 cells, and transfected cells were treated with different concentrations of cpd E or DAPT. Consistent with the levels of NICD that was freshly generated in cultured cells, luciferase activities were inhibited by relatively high doses of cpd E and DAPT. At the concentrations of cpd E and DAPT that completely blocked $A \beta$ generation (Fig. $2 B$ and $2 C$ ), about $50 \%$ luciferase activities remained, i.e., inhibition of NICD generation was less efficient compared to $\mathrm{A} \beta$ blockage (Fig. 2D).

\section{A chimeric APP-Notch ELISA differentiates cpd $E$ in inhibiting APP versus chimeric APP-Notch}

Two cDNA constructs expressing chimeric APP and Notch were previously reported to generate chimeric "Notch-A $\beta$ like" (N $\left.\beta^{*}\right)$ peptide [68]. One construct has its transmembrane domain (TMD) replaced by the Notch TMD (APP-
$\mathrm{m}-\mathrm{NOTCH}$ ) and the other with the juxtamembrane portion of the APP ectodomain (the $\alpha$-secretase cleavage region) replaced by the corresponding sequence in Notch (APP- $\alpha-N O T C H)$ [68]. Taking advantage of different combinations of ELISA antibodies (see Methods), effects of cpd $E$ on the generation of $A \beta$ and $N \beta{ }^{*}$ peptides from these chimeric APP-Notch substrates were quantified by ELISA.

Individual construct APP, APP- $\alpha$-Notch or APP-m-Notch was transiently transfected into HEK293 cells. These chimeric protein expressing cells were treated with cpd E, and the levels of $\mathrm{A} \beta$ and $\mathrm{N} \beta^{*}$ were measured by ELISA. Again, it was found that the effective concentration (EC) for inhibiting $50 \%$ of $A \beta$ production by cpd $E$ was less than $0.1 \mathrm{nM}$, but the $\mathrm{EC}_{50}$ for $\mathrm{N} \beta^{*}$ from $\alpha$-Notch was at $\sim 8 \mathrm{nM}$ (Fig. 3A). Similar results were obtained when m-Notch was expressed in HEK293 cells. At least two magnitude of difference was observed, with $\mathrm{EC}_{50}$ for cpd $\mathrm{E}$ was 0.03 $\mathrm{nM}$ for APP, compared to $\mathrm{EC}_{50}$ for $\mathrm{N} \beta^{*}$ at $\sim 1 \mathrm{nM}$ (Fig. $3 \mathrm{~B}$ ).

\section{Defective zebrafish phenotypes illustrated inhibition of Notch signaling}

Measurements of in vitro $\gamma$-secretase activity and cell-based $A \beta /$ NICD generation have shown different inhibition potencies. To examine the inhibitory effect in vivo, zebrafish embryos were treated with DAPT or cpd E. Because different $\gamma$-secretase inhibitors may impact various metabolic pathways in zebrafish embryos, especially during development, the phenotypes of zebrafish embryos treated with high concentrations of DAPT and cpd E were compared. The major phenotype we examined was curved tail caused by defective somitogenesis.

Morphological alteration in DAPT- or cpd E-treated embryos was compared and correlated to the somitogenesis associated with the inhibition of Notch signaling. The treated embryos were examined using a stereomicroscope and it was found that embryos treated with $50 \mu \mathrm{M}$ DAPT had a much shorter and curved tail, compared to control DMSO-treated embryos (Fig. 4A). The curvature was obvious when a lateral view of zebrafish was obtained. Cpd E, on the other hand, did not show any curvature when treated at $50 \mu \mathrm{M}$. Because the $\mathrm{EC}_{50}$ values for DAPT and cpd $\mathrm{E}$ to reduce NICD generation in cultured cells were $\sim 1000 \mathrm{nM}$ and $10 \mathrm{nM}$, respectively (Fig. 2B and 2C), 50 $\mu \mathrm{M}$ of DAPT and cpd $\mathrm{E}$ were chosen as the highest concentrations for the treatment.

When embryos were kept for four days, embryos treated with $50 \mu \mathrm{M}$ DAPT continued to show the curvature of the tails (Fig. 4B). DMSO-treated embryos exhibited normal morphology with straight trunk and tail. Cpd E had a minor effect on embryo morphology, and the embryos maintained straight trunk and tails (Fig. 4B). 


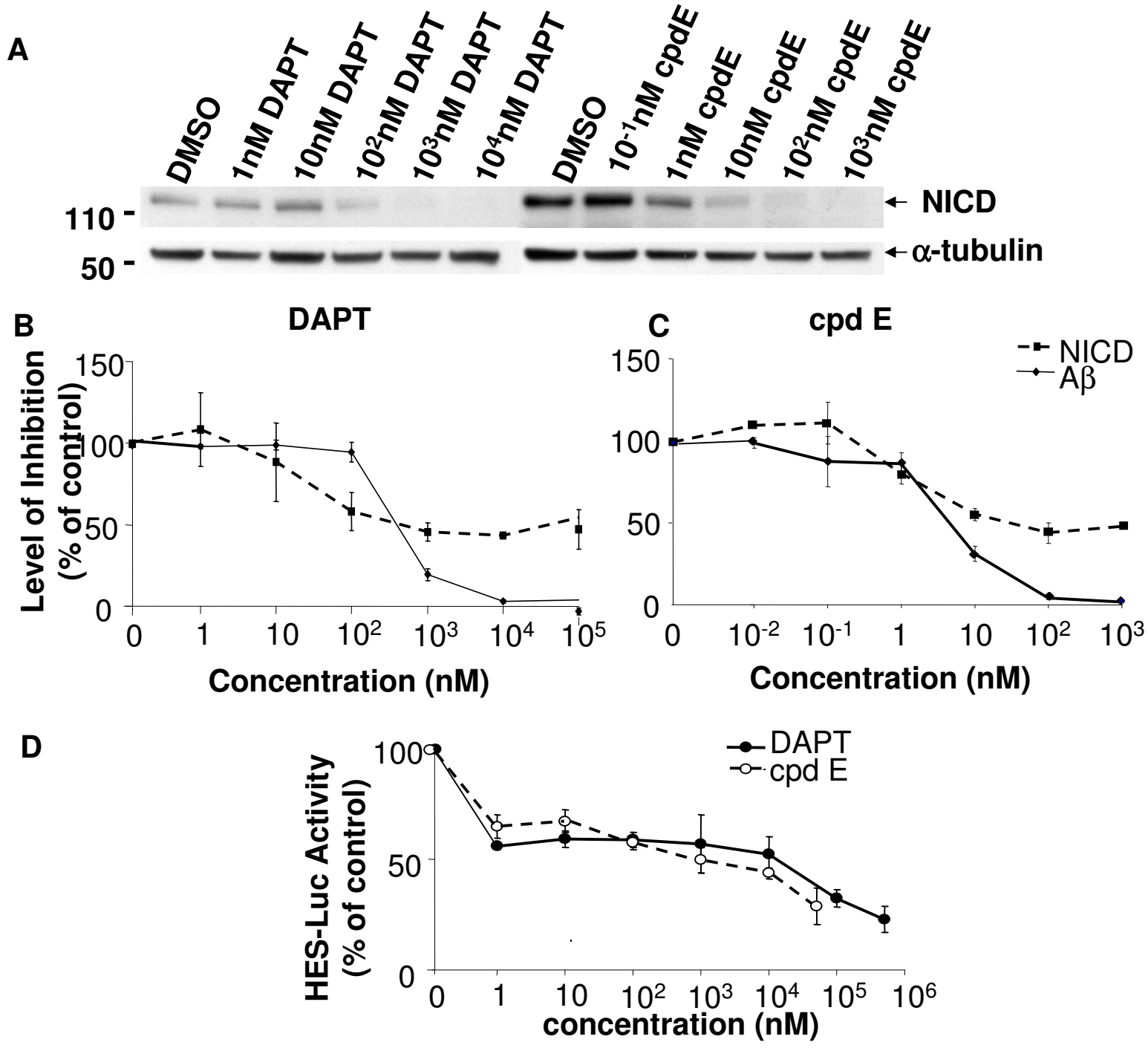

Figure 2

Generation of NICD and A $\beta$ from Notch $\triangle E$ and APP expressing cells. A. Twenty four hrs after the construct carrying Notch $\triangle E$ was transfected into APP expressing HEK293 cells, cells were treated with DAPT or cPd E for $8 \mathrm{hr}$ and lysed for WB with antibody 1744 to specifically detect the $\mathrm{N}$-terminus of NICD. Bottom panel, the antibody against $\alpha$-tubulin was applied to normalize the amounts of lysates used for WB. B. Levels of NICD determined by WB were quantified by densitometry (dotted line). Levels of $A \beta$ generated from the $\gamma$-secretase cleavage of APP in the presence of DAPT were determined by ELISA. Comparison of NICD and A $\beta$ generation in the presence of DAPT suggests that high concentrations of DAPT had a greater inhibition of $A \beta$ than NICD. C. NICD (dotted line) and $A \beta$ (solid line) production from cpd E-treated cells were compared. Cpd $E$ inhibited $A \beta$ generation with an $I C_{50}$ of $\sim 8 \mathrm{nM}$, and it shows a greater inhibition of $A \beta$ than NICD. D. A luciferase reporter construct driven by HESI promoter was transfected into HEK293 cells followed by treatment with cpd E or DAPT. Both $\gamma$ secretase inhibitors blocked transcriptional activation of NICD dependent luciferase activity.

Expression of Notch target gene her6 correlates with the phenotypes of zebrafish treated with $\gamma$-secretase inhibitors To examine the effect of DAPT and cpd E on Notch signaling, embryos treated with different concentrations of DAPT or cpd E were stained by whole mount in situ hybridization using a her6 probe (Fig 5). The expression level of Notch downstream target gene her6 correlates to the levels of Notch signaling, i.e., a loss of her6 staining corresponds to an inhibition of $\gamma$-secretase mediated Notch signaling. We have focused on the specific effect of $\gamma$-secretase inhibitors on Notch signaling in brain region.

In DMSO-treated embryos, her6 expression was mainly clustered in the ventral midbrain and ventral hindbrain 

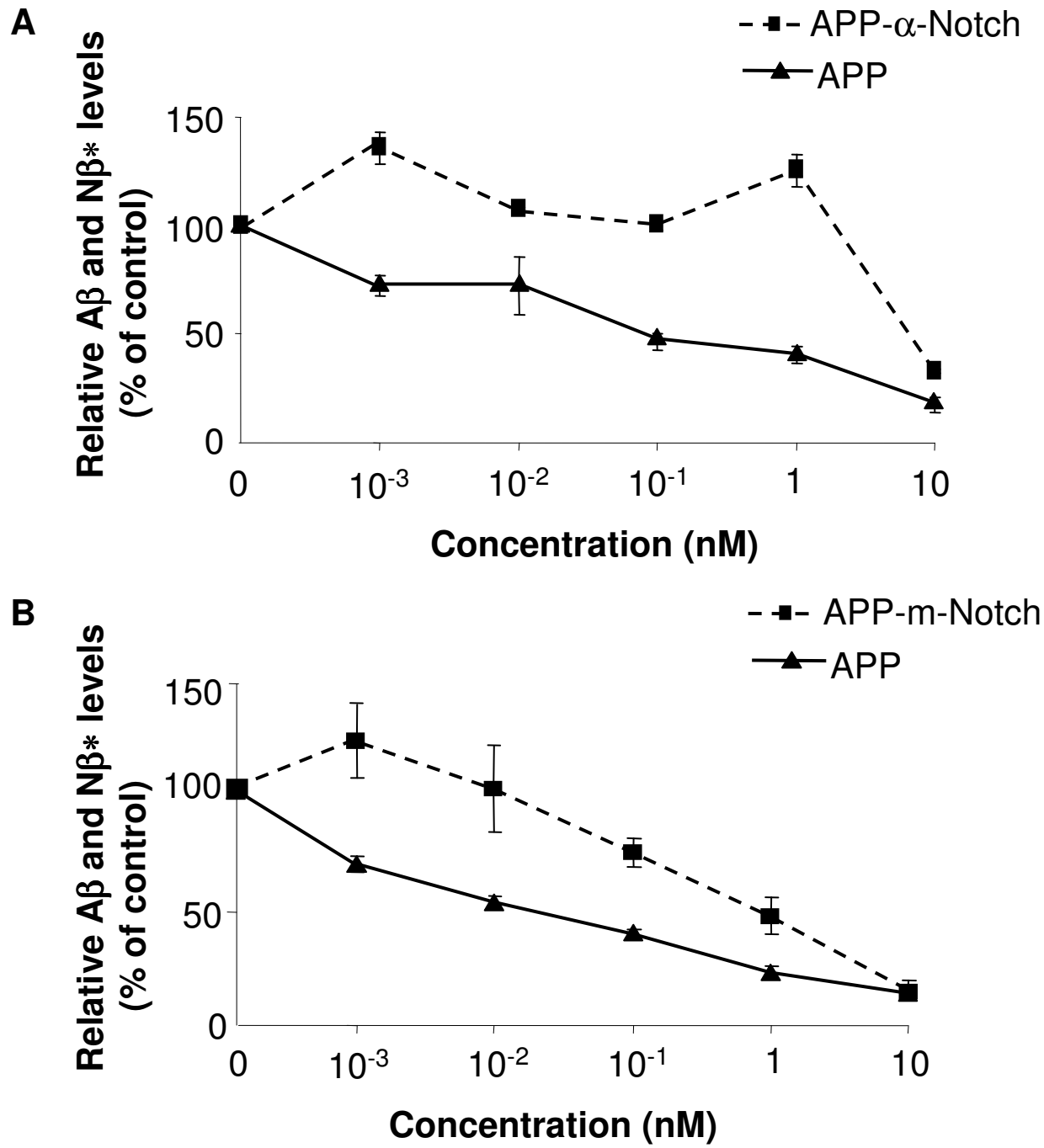

Figure 3

Generation of $\mathbf{A} \beta$ and $\mathbf{N} \beta *$ from chimeric APP-Notch expressing cells. A. The juxtamembrane portion of the APP ectodomain (the $\alpha$-secretase cleavage region) was replaced by the corresponding sequence in Notch $(\alpha-\mathrm{NOTCH})$. Levels of $\mathrm{N} \beta^{*}$ in the media from cells expressing APP- $\alpha$-Notch (dotted line) and levels of A $\beta$ from APP expressing cells (solid line) were determined by ELISA. B. A chimeric cDNA constructs express APP with its transmembrane domain (TMD) replaced by the Notch TMD (APP-m-NOTCH). Levels of $A \beta$ (solid line) and $N \beta^{*}$ (dotted line) were determined by ELISA.

(Fig. 5). In the presence of $50 \mu \mathrm{M}$ DAPT, the her6 expression was significantly reduced or disappeared in most areas, reflecting a strong inhibition of $\gamma$-secretase activity. When embryos were treated with a lower concentration of DAPT at $5 \mu \mathrm{M}$, staining of her 6 started to appear in those areas found in DMSO-treated embryos. Embryos treated with $0.5 \mu \mathrm{M}$ DAPT showed a very similar staining pattern to the control embryos. Interestingly, cpd E showed a weaker effect on the expression levels of her6. There was a reduction of her6 staining in those embryos that were treated with highest testing doses of cpd E. When the her6 staining is linked to morphological alterations (Fig. 5), the level of reduction in Notch signaling is closely linked with the severity of phenotypes that was observed in these zebrafish, i.e., the curvature of the tails.

\section{Discussion}

Our knowledge of $\gamma$-secretase components distinguishing different substrates provides a molecular basis for the modulation of $\gamma$-secretase complex. Nicastrin has been found to interact with both APP and Notch and is involved in substrate recognition and interaction [36]. An 
A. $2 \mathrm{dpf}$

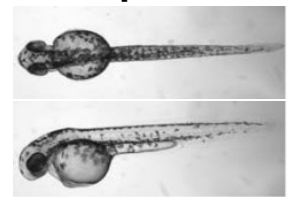

$0.5 \%$ DMSO
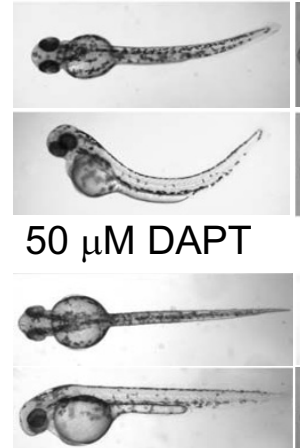

$50 \mu \mathrm{M} c p d \mathrm{E}$

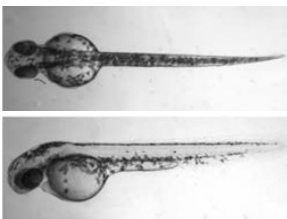
$5 \mu \mathrm{M}$ DAPT

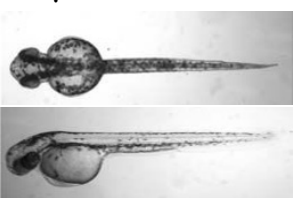

$5 \mu \mathrm{M}$ cpd E
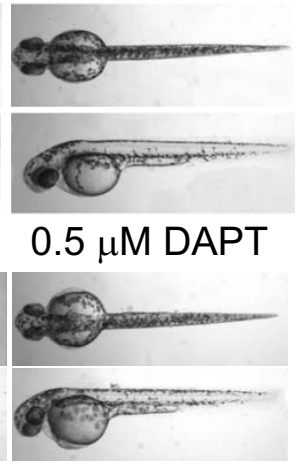

$0.5 \mu \mathrm{M} \operatorname{cpd} \mathrm{E}$

\section{B. $4 \mathrm{dpf}$}
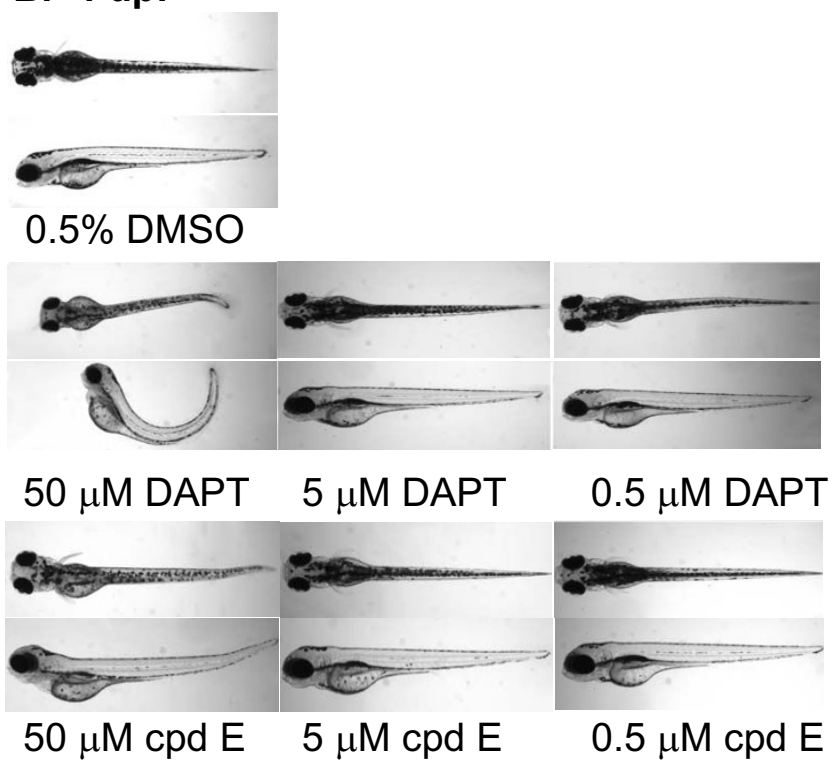

\section{Figure 4}

Treatment of zebrafish embryos with DAPT causes curved tails. A. A stock of DAPT or cPd E in DMSO was diluted in embryo medium, and increasing concentrations of DAPT or cpd E were applied to de-chorionated zebrafish embryos incubated at $28^{\circ} \mathrm{C}$ from $24 \mathrm{hpf}$ to $48 \mathrm{hpf}$. Control embryos were mock-treated with embryo medium containing the same concentration of DMSO. Treatment of zebrafish embryos with $50 \mu \mathrm{M}$ DAPT caused curved trunk and tails. B. DAPT- or cpd E-treated embryos were kept until $4 \mathrm{dpf}$, and images were acquired at $40 \times$ magnification.

artificial elongation of the Pen-2 $\mathrm{N}$-terminus leads to an increased $A \beta_{42}$ production [69], indicating that Pen-2 might function as a modulator to influence the $\gamma$-secretase cleavage of APP. Identification of a key regulator of $\gamma$ secretase complex TMP21 further suggests that cleavage of APP and Notch could be distinguished and modulated [70]. While the development of $\gamma$-secretase inhibitors is one of the major directions for $\mathrm{AD}$ therapeutics, completely blocking the $\gamma$-secretase-mediated proteolytic process of about 50 substrates interferes with fundamental steps in many biological functions. Therefore, identifying $\gamma$-secretase modulators that only block the cleavage of APP, but not other substrates is ideal. Different from earlier studies that have identified NSAIDs and Gleevec for specific blockage of $A \beta$ production without affecting the $\gamma$ secretase cleavage of Notch, the current study has provided a systematic approach to identify $\gamma$-secretase inhibitors to modulate the $\gamma$-secretase cleavage of APP and Notch separately.

We have analyzed two potent $\gamma$-secretase inhibitors DAPT and cpd $\mathrm{E}$ using different quantification methods to determine the pharmacological profile of blocking the cleavage of APP and Notch. The range of inhibition concentrations vary among these methods. However, the effective inhib- itory concentrations for Notch cleavage were always found to be higher than those concentrations for APP cleavage. In a conventional in vitro $\gamma$-secretase activity assay, $0.1 \mu \mathrm{M}$ of cpd E completely blocked $\mathrm{A} \beta$ generation from the cleavage of substrate APP C100, and only had minor effect on Notch cleavage and NICD generation. Cpd E selectively inhibited the $\gamma$-secretase cleavage of APP at low concentrations, i.e., from $0.1 \mathrm{nM}$ to $10 \mathrm{nM}$. However, at the same concentrations, we found that DAPT did not inhibit the $\gamma$-secretase cleavage of APP and Notch (Fig. 1C). When higher concentration of DAPT was used in our in vitro $\gamma$-secretase activity assay, a partial inhibition of Notch cleavage was observed, in contrast to an almost complete inhibition of APP cleavage. Therefore, DAPT selectively blocked the $\gamma$-secretase cleavage of APP at higher concentration compared to compound $\mathrm{E}$. When cpd E or DAPT were applied to HEK293 cells that expressed the substrate Notch $\Delta \mathrm{E}$, we found that both compounds were more potent in blocking $\mathrm{A} \beta$ generation than NICD production. DAPT at concentrations of $1 \mu \mathrm{M}$ or higher reduced Notch cleavage to about $50 \%$ in both in vitro $\gamma$-secretase activity assay (Fig. 1B) and cell culture based assay (Fig. 2B). Cpd E at $0.1 \mu \mathrm{M}$ reduced Notch cleavage to $\sim 50 \%$ in both systems. For the $\gamma$-secretase cleavage of APP, DAPT was able to inhibit the levels of A $\beta$ 


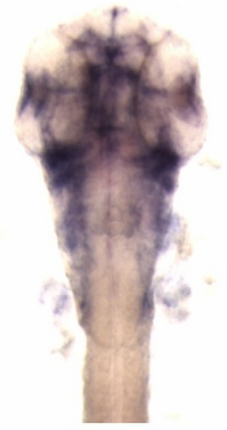

$0.5 \%$ DMSO

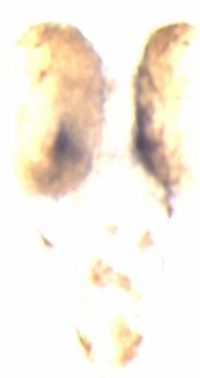

$50 \mu \mathrm{M}$ DAPT

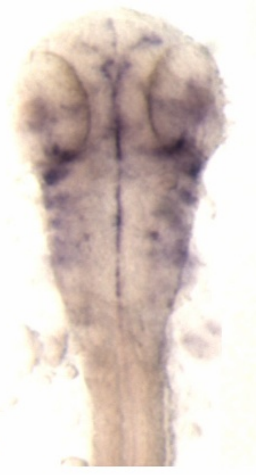

$50 \mu \mathrm{M} \operatorname{cpd} \mathrm{E}$

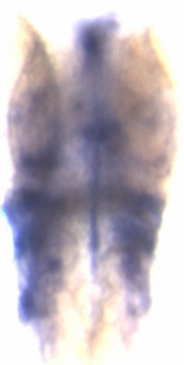

$5 \mu \mathrm{M}$ DAPT

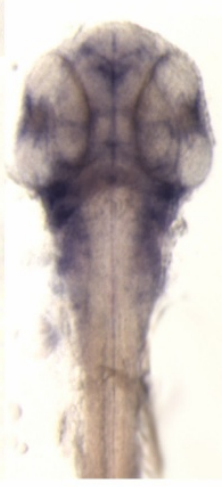

$5 \mu \mathrm{M} \operatorname{cpd} \mathrm{E}$

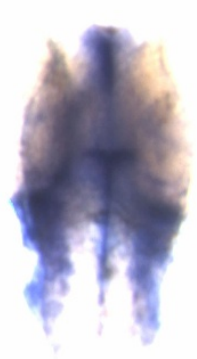

$0.5 \mu \mathrm{M}$ DAPT

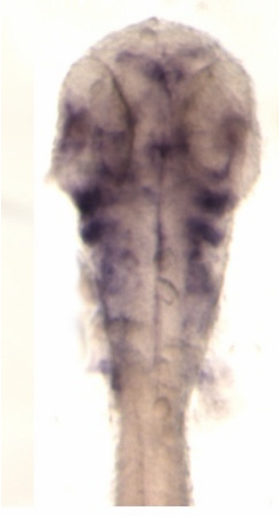

$0.5 \mu \mathrm{M} \operatorname{cpd} \mathrm{E}$

\section{Figure 5}

Expression levels of Notch target gene her6 are consistent with the curvature phenotype. Increasing concentrations of DAPT or cpd E were applied to de-chorionated zebrafish embryos from $24 \mathrm{hpf}$ until $48 \mathrm{hpf}$, and in situ hybridization of compound-treated embryos was carried out at $48 \mathrm{hpf}$ using the her6 probe. At least 10 to 20 embryos were examined for each experiment. Images were taken at the $64 \times$ magnification for stained embryos.

to $50 \%$ at the concentration of $1 \mu \mathrm{M}$ in vitro and $\sim 0.5 \mu \mathrm{M}$ in cultured cells, respectively. Compound $\mathrm{E}$, on the other hand, was able to reduce the levels of $A \beta$ to $50 \%$ at the concentrations of $1 \mathrm{nM}$ and $5 \mathrm{nM}$ in two systems. Therefore, DAPT and cpd E showed similar potencies in cultured cells and in vitro $\gamma$-secretase activity assay. The level of NICD inhibition was consistent with the reduced expression of Luciferase gene driven by a Notch target gene promoter containing three $\mathrm{Su}(\mathrm{H})$ binding sequences. Using two previously reported chimeric cDNA constructs expressing APP-m-NOTCH or APP- $\alpha-N O T C H$, cpd E showed much higher $\mathrm{EC}_{50}$ 's for lowering the levels of $\mathrm{N}^{*}$ derived from the cleavage of APP-m-NOTCH and APP- $\alpha-N O T C H$. Finally, the expression levels of Notch target gene her6 in a whole animal zebrafish, as measured by in situ hybridization, were correlated with the dosedependent phenotypic effect of DAPT. The effect of cpd E was less obvious and hence, consistent with a less reduction of her 6 expression.
Previous studies have applied similar compounds to differentiate their effect on the $\gamma$-secretase cleavage of Notch and APP, and some showed selective inhibition of A $\beta$ production without Notch phenotypes in animals [71]. Lewis et al. have used a set of compounds for the test, and some of these compounds (like compound 1) have similar structures to DAPT [72]. Using cultured cells to test the potencies of different compounds, they found that Notch and APP cleavages cannot be easily dissected apart [72]. We have used additional methods to determine the inhibition profile of DAPT and cpd E, including in vivo animal based assays. In cultured cells expressing Notch $\Delta \mathrm{E}$ or chimeric APP-Notch proteins, cpd E was more effective in inhibiting APP than Notch substrate. DAPT showed similar effect in cultured cells and in an in vitro $\gamma$-secretase activity assay. Both $\gamma$-secretase inhibitors DAPT and cpd E are believed to interact with the core component of the $\gamma$ secretase complex, PS. Mutation of two aspartate residues in PS1 leads to a complete loss of function for $\gamma$-secretase 
which suggests that these two aspartates may constitute the active site of $\gamma$-secretase [27]. Both aspartyl protease transition state mimic and non-transition-state $\gamma$-secretase inhibitor could specifically bind the $\mathrm{N}$ - and C-terminal fragments of PS1 $[73,46,57]$. The binding of the $\gamma$-secretase inhibitor to PS1 NTF/CTF could be then competitively suppressed by the presence of cpd E [57]. DAPT was found to specifically interact with the C-terminal region of PS1 [59]. Studies that use helical peptide inhibitors to block the $\gamma$-secretase complex suggest that a docking and an active site exist for the $\gamma$-secretase complex, and that the docking site might be located at the PS subunit interface, a site very close to the active site [74]. It is not clear whether different concentrations of DAPT and cpd E may affect the docking site in a way that differentiate the binding of APP and Notch to the $\gamma$-secretase complex.

Both DAPT and cpd E have been used to treat animals. DAPT was specifically tested in zebrafish [61]. Zebrafish have a highly conserved $\gamma$-secretase complex. Both zebrafish PS1 (Psen1) and the PS2 homolog (Psen2) are expressed during the segmentation and later stages [7577]. Nicastrin has been identified in the zebrafish genome, and only one copy of Psen1, Psen2, Pen-2, and Aph-1 gene has been found [30]. Once the highly similar zebrafish $\gamma$-secretase complex is inhibited by DAPT, somitogenesis is severely affected leading to curved tails, a phenotype well-characterized for altered Notch signaling [61]. In this study, a dose dependent effect of DAPT on zebrafish phenotypes was observed, and a curvature of zebrafish tail was found in embryos treated with $50 \mu \mathrm{M}$ of DAPT. Although the $\mathrm{EC}_{50}$ of DAPT for inhibiting Notch signaling was much lower in cultured cells $(1-10 \mu \mathrm{M}$, Fig. 2 ), it is not surprising that a high concentration of DAPT was necessary to induce a phenotype in a whole animal (50 $\mu \mathrm{M}$, Fig. 4). For cpd E, the highest concentration used to treat embryos was $50 \mu \mathrm{M}$ compared to an $\mathrm{EC}_{50}$ that was below $0.1 \mu \mathrm{M}$ for the inhibition of NICD generation in cultured cells (Fig. 2). For both DAPT and cpd E, there is no data on pharmacokinetics, pharmacodynamics and ADME of these two compounds in zebrafish. While both cpd E and DAPT are cell permeable, a lack of dramatic phenotypic alteration in embryos treated with $50 \mu \mathrm{M}$ cpd E could be best explained by a slightly reduced expression level of her 6 gene. This indicates that Notch signaling was not significantly perturbed at this concentration of cpd $\mathrm{E}$ in a whole animal.

Administration of cpd $\mathrm{E}$ into guinea pig resulted in a dosedependent inhibition of brain cortical $\gamma$-secretase activity and correspondingly, decreases in plasma, CSF and brain $\mathrm{A} \beta$ levels [78]. Treatment of a transgenic mouse expressing human familial AD linked V717F APP with DAPT also leads to a dose-dependent, acute decrease in brain $A \beta$ [79]. Treatment of AD patients with another $\gamma$-secretase inhibitor, LY450139 dihydrate, reduces plasma $A \beta 40$. This compound was well tolerated in these patients [8082]. Therefore, modulated inhibition of $\gamma$-secretase is feasible in human subjects, and potent inhibitors used at appropriate doses appear to be promising in preventing the progression of $A \beta$ pathology.

\section{Conclusion}

Our measurement of $A \beta$ and Notch-A $\beta$-like peptides from chimeric APP proteins could be used for efficient cellbased screening of $\gamma$-secretase modulators. These modulators could be tested by in vitro $\gamma$-secretase activity assay. The in vivo test results presented here of these compounds in a vertebrate zebrafish further validate our quantitative methods to differentiate their selectivity for APP, Notch and potentially other $\gamma$-secretase substrates.

\section{Methods}

\section{In Vitro $\gamma$-Secretase Activity Assay}

The E. coli generated APP- and Notch-based, 100-residue $\gamma$-secretase substrates C100-Flag and N100-Flag were purified as previously described [65]. C100-Flag substrate contains an initiating methionine, the $99 \mathrm{C}$-terminal residues of APP that start at the $\alpha$-secretase site, and a Flag tag. N100-Flag substrate contains a similar initiating methionine, 99 amino acids that start at the TACE cleavage site, and a Flag tag. The membrane vesicles were solubilized in $1 \%$ CHAPSO-HEPES and diluted in a final concentration of $0.2 \%$ CHAPSO-HEPES. Phosphatidylethanolamine (PE) and phosphatidylcholine (PC) were added to the final concentration of $0.02 \% \mathrm{PE}$ and $0.08 \%$ PC. After adding DMSO or test compounds to the solubilized $\gamma$-secretase complex, substrate C100-Flag or N100-Flag was added to the mixture, then followed by incubation at $37^{\circ} \mathrm{C}$ for 4 hours $[65,83]$. Two compounds have been used in this study, compound E (cpd E), \{(S,S)-2-[2- $(3,5-$ Difluorophenyl)-acetylamino]-N-(1-methyl-2-oxo-5-

phenyl-2,3-dihydro-1H-benzo [e] [1,4] diazepin-3-yl)propionamide $\}$ [57] and DAPT $\{\mathrm{N}-[\mathrm{N}-(3,5$-Difluorophenacetyl-L-alanyl)]-S-phenylglycine $t$-Butyl Ester $\}$ [79]. Cpd E was provided by Dr. Michael Wolfe.

\section{ELISAs and Antibodies}

Sandwich ELISAs for A $\beta$ were performed as described [84]. The capture antibodies, 2G3 (to $A \beta$ residues 33-40) and $4 \mathrm{G} 8$ (to $A \beta$ residues $17-24$ ), were used for $A \beta 40$ and $A \beta$ total species, respectively. The detecting antibodies were biotinylated 82E1 (to $A \beta$ residues 1-16) for $A \beta 1-40 /$ total or biotinylated 266 for $A \beta x-40$ species. The use of midregion and C-terminal capturing antibodies and $\mathrm{N}$-terminal detecting antibody for chimeric "Notch-A $\beta$-like" peptide $\left(\mathrm{N} \beta^{*}\right)$ has been documented [68]. The combination of several capture/detecting antibodies are use to measure $A \beta$ and $N \beta^{*}$ derived from different precursors. The capture antibody $2 \mathrm{G} 3$ and detecting antibody $82 \mathrm{E} 1$ were used 
for measuring $N \beta^{*}$ from APP- $\alpha$-Notch expressing cells. Since the APP- $\alpha$-NOTCH is the fusion protein with its juxtamembrane portion of the APP ectodomain (the $\alpha$-secretase cleavage region) replaced by the corresponding sequence in Notch, the epitopes in APP sequence could still be recognized by 2G3 (C-terminus) and 82E1 (N-terminus). The capture antibody 4G8 and detecting antibody 82E1 were used for measuring $\mathrm{N}^{*}$ from APP-m-Notch expressing cells. Since the APP-m-NOTCH is the fusion protein with its transmembrane domain (TMD) replaced by the Notch TMD, the epitopes in APP sequence could be recognized by 4G8 (mid-region before TMD) and 82E1 (N-terminus). Antibody 82E1 was purchased from Immuno-Biological Laboratories, Inc., Minneapolis, MN. Antibody 4G8 was purchased from Signet Laboratories, Inc., Dedham, MA. Antibody 1744 that specifically detect the N-terminus of NICD was purchased from Cell Signaling Technology, Danvers, MA.

\section{cDNA constructs for cell based $\gamma$-secretase activity assay}

The cDNA construct Notch $\Delta \mathrm{E}$ has a c-myc tag and is a truncated Notch molecule that is an immediate substrate for $\gamma$-secretase cleavage to generate Notch intracellular domain (NICD) [85]. Two chimeric cDNA constructs express APP with (APP-m-NOTCH), or else the juxtamembrane portion of the APP ectodomain (the $\alpha$-secretase cleavage region) replaced by the corresponding sequence in Notch (APP- $\alpha$-NOTCH). These cDNA constructs were provided by Dr. Dennis Selkoe [68]. Hes-1 reporter construct (Hes-Luc) was generated by insertion three of $\mathrm{Su}(\mathrm{H})$ binding sequence

\section{5'-AGGTTCTCACTGTGGGGTAAGAAGGTTCTCACAGT-} GGGGTAAGAGGTTCTCACAGTC in the pGL3-pro luciferase reporter vector (Promega, Madison, WI). The final assemble is similar to a previously reported Notch reporter construct [86].

Human embryonic kidney (HEK) 293 cells stably expressing Swedish mutant human APP695 were transfected with different cDNA constructs and maintained in $200 \mu \mathrm{g} / \mathrm{ml}$ G418 (Invitrogen, Carlsbad, CA). Transfected cells were treated with two $\gamma$-secretase inhibitors cpd E or DAPT for $8 \mathrm{hr}$. Conditioned media were collected for ELISA, and cell lysates were analyzed by Western blot as described [87]. Cells co-transfected with Hes-Luc and Notch $\Delta$ E were treated with compounds followed by the measurement of luciferase activity (Luciferase Assay System, Promega, Madison, WI).

\section{Zebrafish Embryo Treatment}

Zebrafish embryos were raised and staged according to Kimmel, et al. [88]. Compounds were dissolved in egg water at various final concentrations, and 0.5\% DMSO was used as a negative control. Prior to the treatment at 24 hour post fertilization, embryos were de-chorionated manually. Embryos were placed in a 24 -well plate (5-6 embryos/well) and treated with the compound containing egg water. Embryos were incubated at $28^{\circ} \mathrm{C}$, and photographic images were taken at 2 days and 4 days post fertilization (dpf).

\section{Microscope Imaging}

Compound-treated embryos were observed under an OLYMPUS SZX12 microscope. For examination, embryos were removed from the compound containing medium and placed into $0.4 \%$ tricane (3-amino benzoic acidethylester, Sigma, St. Louis, MO) solution. Upon anesthetizing, embryos were placed in 3\% methylcellulose for positioning and images were recorded with OLYMPUS QCOLOR3 camera. Images were taken at the $40 \times$ magnification for embryos at 2 and $4 \mathrm{dpf}$.

\section{In situ Hybridization}

In situ hybridization of compound-treated embryos was carried out at $2 \mathrm{dpf}$ according to standard protocols [89] using the her 6 probe. Single-stranded RNA probes against her6 were synthesized from a cDNA clone (provided by Dr. P Raymond, University of Michigan, Ann Arbor, MI) using T7 RNA polymerase after linearization by restriction digest. The probe was then labeled with digoxigenin-UTP (Roche, Basel, Switzerland). At least 10 to 20 embryos were examined for each experiment. Images were taken at $64 \times$ magnification for stained embryos.

\section{Abbreviations}

$\mathrm{AD}$ : Alzheimer's disease; $\mathrm{A} \beta$ : amyloid $\beta$ protein; APP: amyloid precursor protein; Abl: Abelson leukemia; cpd E: compound $\mathrm{E}$; dpf: days post fertilization; EC: effective concentration; HEK: human embryonic kidney; hpf: hours post fertilization; $N \beta^{*}$ : Notch-A $\beta$-like; NICD: Notch intracellular domain; PS: Presenilin; TMD: transmembrane domain; WB: Western blot.

\section{Competing interests}

The authors declare that they have no competing interests.

\section{Authors' contributions}

TY participated in the design of the study and carried out biochemical studies, DA carried out the zebrafish assays, YG and CAS provided reagents and intellectual contribution to the in vitro $\gamma$-secretase activity assay, WX conceived of the study, participated in its design, and drafted the manuscript. All authors read and approved the final manuscript.

\section{Acknowledgements}

We would like to thank Dr. Dennis Selkoe for providing cDNA constructs, Dr. Michael Wolfe for providing cpd E, Dr. Peter Seubert and Dr. Dale

Schenk for ELISA antibodies, Dr. Pamela Raymond for the cDNA carrying 
her6, Dr. Pamela Osenkowski and Wenjuan Ye for helpful discussions. This work was supported by NIH grant AG0I5379 (WX).

\section{References}

I. Selkoe DJ: Alzheimer disease: mechanistic understanding predicts novel therapies. Ann Intern Med 2004, I 40(8):627-638.

2. Haass C, Schlossmacher M, Hung AY, Vigo-Pelfrey C, Mellon A, Ostaszewski B, Lieberburg I, Koo EH, Schenk D, Teplow D, et al.: Amyloid b-peptide is produced by cultured cells during normal metabolism. Nature 1992, 359:322-325.

3. Shoji M, Golde TE, Ghiso J, Cheung TT, Estus S, Shaffer LM, Cai X, McKay DM, Tintner R, Frangione B, et al.: Production of the Alzheimer amyloid b protein by normal proteolytic processing. Science 1992, 258: 126-129.

4. De Strooper B, Annaert W, Cupers P, Saftig P, Craessaerts K, Mumm JS, Schroeter EH, Schrijvers V, Wolfe MS, Ray WJ, et al.: A presenilin-I-dependent gamma-secretase-like protease mediates release of Notch intracellular domain. Nature 1999, 398(6727):518-522.

5. Okochi M, Steiner H, Fukumori A, Tanii H, Tomita T, Tanaka T, Iwatsubo T, Kudo T, Takeda M, Haass C: Presenilins mediate a dual intramembranous gamma-secretase cleavage of Notch-I. Embo J 2002, 2 I (20):5408-54l6.

6. Fortini ME: Gamma-secretase-mediated proteolysis in cellsurface-receptor signalling. Nat Rev Mol Cell Biol 2002, 3(9):673-684.

7. Kopan R, Goate A: Aph-2/Nicastrin: an essential component of gamma-secretase and regulator of Notch signaling and Presenilin localization. Neuron 2002, 33(3):32I-324.

8. Taniguchi Y, Kim SH, Sisodia SS: Presenilin-dependent "gammasecretase" processing of deleted in colorectal cancer (DCC). J Biol Chem 2003, 278(33):30425-30428.

9. Ni CY, Murphy MP, Golde TE, Carpenter G: gamma-Secretase Cleavage and Nuclear Localization of ErbB-4 Receptor Tyrosine Kinase. Science 200I, 294(5549):2 I79-2 I8I.

10. Lee HJ, Jung KM, Huang YZ, Bennett LB, Lee JS, Mei L, Kim TW: Presenilin-dependent gamma-secretase-like intramembrane cleavage of ErbB4. J Biol Chem 2002, 277(8):63 I8-6323.

II. Marambaud P, Shioi J, Serban G, Georgakopoulos A, Sarner S, Nagy V, Baki L, Wen P, Efthimiopoulos S, Shao Z, et al.: A presenilin-I/ gamma-secretase cleavage releases the E-cadherin intracellular domain and regulates disassembly of adherens junctions. Embo J 2002, 2 I(8): 1948-1956.

12. Marambaud P, Wen PH, Dutt A, Shioi J, Takashima A, Siman R, Robakis NK: A CBP binding transcriptional repressor produced by the PSI/epsilon-cleavage of $\mathrm{N}$-cadherin is inhibited by PS I FAD mutations. Cell 2003, I I 4(5):635-645.

13. Lammich S, Okochi M, Takeda M, Kaether C, Capell A, Zimmer A-K, Edbauer D, Walter J, Steiner H, Haass C: Presenilin dependent intramembrane proteolysis of CD44 leads to the liberation of its intracellular domain and the secretion of an Abeta-like peptide. J Biol Chem 2002, 277:44754-44759.

14. Murakami D, Okamoto I, Nagano OKY, Tomita T, Iwatsubo T, De Strooper B, Yumoto E, Saya H: Presenilin-dependent gammasecretase activity mediates the intramembranous cleavage of CD44. Oncogene 2003, 22:15II-1516.

15. May P, Reddy YK, Herz J: Proteolytic processing of low density lipoprotein receptor-related protein mediates regulated release of its intracellular domain. J Biol Chem 2002, 277(2 I): |8736-18743.

16. Kim D, Ingano L, Kovacs D: Nectin-I a, an immunoglobulin-like receptor involved in the formation of synapses, is a substrate for presenilin/g-secretase-like cleavage. J Biol Chem 2002, 277:49976-4998I.

17. Ikeuchi T, Sisodia S: The Notch ligands, Delta I and Jagged2, are substrates for presenilin-dependent "gamma-secretase" cleavage. J Biol Chem 2003, 278(I 0):775I-7754.

18. Meyer E, Strutz N, Gahring LCRS: Glutamate Receptor Subunit 3 Is Modified by Site-specific Limited Proteolysis Including Cleavage by \{gamma\}-Secretase. J Biol Chem 2003, 278(26):23786-23796.

19. Scheinfeld MH, Ghersi E, Laky K, Fowlkes BJ, D'Adamio L, Roncarati R, Sestan N, Berechid BE, Lopez PA, Meucci O, et al.: Processing of beta-amyloid precursor-like protein-I and -2 by gamma- secretase regulates transcription. I Biol Chem 2002, 277(46):44195-4420I.

20. Walsh DM, Fadeeva JV, LaVoie MJ, Paliga K, Eggert S, Kimberly WT, Wasco W, Selkoe DJ: gamma-Secretase cleavage and binding to FE65 regulate the nuclear translocation of the intracellular C-terminal domain (ICD) of the APP family of proteins. Biochemistry 2003, 42(22):6664-6673.

21. Eggert S, Paliga K, Soba P, Evin G, Masters CL, Weidemann A, Beyreuther $\mathrm{K}$ : The proteolytic processing of the amyloid precursor protein gene family members APLP-I and APLP-2 involves alpha -, beta -, gamma -, and epsilon -like cleavages. Modulation of APLP-I processing by $\mathbf{N}$-glycosylation. J Biol Chem 2004, 279:18|46-|8|56.

22. Kanning KC, Hudson M, Amieux PS, Wiley JC, Bothwell M, Schecterson LC: Proteolytic processing of the p75 neurotrophin receptor and two homologs generates C-terminal fragments with signaling capability. J Neurosci 2003, 23( I 3):5425-5436.

23. Schulz JG, Annaert W, Vandekerckhove J, Zimmermann P, De Strooper B, David G: Syndecan 3 intramembrane proteolysis is presenilin/gamma-secretase-dependent and modulates cytosolic signaling. J Biol Chem 2003, 278(49):4865 I-48657.

24. Wilhelmsen K, Geer P van der: Phorbol I 2-myristate I 3-acetateinduced release of the colony-stimulating factor I receptor cytoplasmic domain into the cytosol involves two separate cleavage events. Mol Cell Biol 2004, 24(I):454-464.

25. Kuhn PH, Marjaux E, Imhof A, De Strooper B, Haass C, Lichtenthaler SF: Regulated intramembrane proteolysis of the interleukinI receptor II by alpha-, beta-, and gamma-secretase. I Biol Chem 2007, 282(16): I 1982-I I995.

26. Xia W, Wolfe M: Intramembrane proteolysis by presenilin and presenilin-like proteases. J Cell Sci 2003, I I 6(Pt I 4):2839-2844.

27. Wolfe MS, Xia W, Ostaszewski BL, Diehl TS, Kimberly WT, Selkoe DJ: Two transmembrane aspartates in presenilin-I required for presenilin endoproteolysis and g-secretase activity. Nature 1999, 398:513-517.

28. Yu G, Nishimura M, Arawaka S, Levitan D, Zhang L, Tandon A, Song YQ, Rogaeva E, Chen F, Kawarai T, et al.: Nicastrin modulates presenilin-mediated notch/glp-I signal transduction and betaAPP processing. Nature 2000, 407(6800):48-54.

29. Chen F, Yu G, Arawaka S, Nishimura M, Kawarai T, Yu H, Tandon A, Supala A, Song Y, Rogaeva E, et al: Nicastrin binds to membranetethered Notch. Nat Cell Biol 200I, 3:75I-754.

30. Francis R, McGrath G, Zhang J, Ruddy D, Sym M, Apfeld J, Nicoll M, Maxwell $M$, Hai $B$, Ellis $M C$, et al.: aph-I and pen-2 are required for Notch pathway signaling, g-secretase cleavage of bAPP and presenilin protein accumulation. Dev Cell 2002, 3:85-97.

31. Lee S, Shah S, Li H, Yu C, Han W, Yu G: Mammalian APH-I Interacts with Presenilin and Nicastrin, and is Required for Intramembrane Proteolysis of APP and Notch. J Biol Chem 2002, 277:45013-45019.

32. Siman R, Velji J: Localization of presenilin-nicastrin complexes and gamma-secretase activity to the trans-Golgi network. J Neurochem 2003, 84(5): I | 43-I I 53.

33. Shirotani K, Edbauer D, Capell ASJ, Steiner H, Haass C: gammaSecretase Activity Is Associated with a Conformational Change of Nicastrin. J Biol Chem 2003, 278(I 9): I 6474-I 6477.

34. Alves da Costa C, Mattson MP, Ancolio K, Checler F: The C-terminal fragment of presenilin 2 triggers p53-mediated staurosporine-induced apoptosis, a function independent of the presenilinase-derived $\mathbf{N}$-terminal counterpart. J Biol Chem 2003, 278( I 4): I 2064- I 2069.

35. Li T, Ma G, Cai H, Price DL, Wong PC: Nicastrin Is Required for Assembly of Presenilin/gamma-Secretase Complexes to Mediate Notch Signaling and for Processing and Trafficking of beta-Amyloid Precursor Protein in Mammals. I Neurosci 2003, 23(8):3272-3277.

36. Shah S, Lee SF, Tabuchi K, Hao YH, Yu C, LaPlant Q, Ball H, Dann CE 3rd, Sudhof T, Yu G: Nicastrin functions as a gamma-secretasesubstrate receptor. Cell 2005, I 22(3):435-447.

37. Goutte C, Tsunozaki M, Hale VA, Priess JR: APH-I is a multipass membrane protein essential for the Notch signaling pathway in Caenorhabditis elegans embryos. Proc Natl Acad Sci 2002, 99(2):775-779.

38. Crystal A, Morais VA, Pierson TC, Pijak DS, Carlin D, Lee VM, Doms RW: Membrane topology of gamma-secretase component PEN-2. J Biol Chem 2003, 278(22):20I I7-20I 23. 
39. Baulac S, LaVoie MJ, Kimberly WT, Strahle J, Wolfe MS, Selkoe DJ, Xia W: Functional gamma-secretase complex assembly in Golgi/ trans-Golgi network: interactions among presenilin, nicastrin, Aph I, Pen-2, and gamma-secretase substrates. Neurobiol Dis 2003, I 4(2): 194-204.

40. De Strooper B: Aph-I, Pen-2, and Nicastrin with Presenilin generate an active gamma-Secretase complex. Neuron 2003, 38(I):9-12.

4I. Hu Y, Fortini M: Different cofactor activities in gamma-secretase assembly: evidence for a nicastrin-Aph-I subcomplex. J Cell Biol 2003, I 6 I (4):685-690.

42. Kimberly W, LaVoie M, Ostaszewski BL, Ye W, Wolfe MS, Selkoe DJ: Gamma-secretase is a membrane protein complex comprised of presenilin, nicastrin, Aph-I, and Pen-2. Proc Natl Acad Sci USA 2003, I 00( I I ):6382-6387.

43. Luo WJ, Wang H, Li H, Kim BS, Shah S, Lee HJ, Thinakaran G, Kim TW, Yu G, Xu H: PEN-2 and APH-I coordinately regulate proteolytic processing of presenilin I. J Biol Chem 2003 278:7850-7854.

44. Takasugi N, Tomita T, Hayashi I, Tsuruoka M, Niimura M, Takahashi $\mathrm{Y}$, Thinakaran $\mathrm{G}$, Iwatsubo $\mathrm{T}$ : The role of presenilin cofactors in the gamma-secretase complex. Nature 2003, 422(6930):438-441.

45. Edbauer D, Winkler E, Regula JT, Pesold B, Steiner H, Haass C: Reconstitution of gamma-secretase activity. Nat Cell Biol 2003, 5:486-488.

46. Esler WP, Kimberly WT, Ostaszewski BL, Diehl TS, Moore CL, Tsai JY, Rahmati T, Xia W, Selkoe DJ, Wolfe MS: Transition-state analogue inhibitors of gamma-secretase bind directly to presenilin- I. Nat Cell Biol 2000, 2(7):428-434.

47. Li Y-M, Xu M, Lai M-T, Huang Q, Castro JL, DiMuzio-Mower J, Harrison T, Lellis C, Nadin A, Neduvelli JG, et al.: Photoactivated gsecretase inhibitors directed to the active site covalently label presenilin I. Nature 2000, 405:689-694.

48. Weggen S, Eriksen JL, Sagi SA, Pietrzik CU, Golde TE, Koo EH: Abeta42-lowering nonsteroidal anti-inflammatory drugs preserve intramembrane cleavage of the amyloid precursor protein (APP) and ErbB-4 receptor and signaling through the APP intracellular domain. J Biol Chem 2003, 278(33):30748-30754.

49. Weggen S, Eriksen JL, Das P, Sagi SA, Wang R, Pietrzik CU, Findlay KA, Smith TE, Murphy MP, Bulter T, et al:: A subset of NSAIDs lower amyloidogenic Abeta42 independently of cyclooxygenase activity. Nature 200I, 4I4(6860):212-2I6.

50. Gasparini L, Rusconi L, Xu H, del Soldato P, Ongini E: Modulation of beta-amyloid metabolism by non-steroidal anti-inflammatory drugs in neuronal cell cultures. J Neurochem 2004, 88(2):337-348.

5I. Qin W, Ho L, Pompl PN, Peng Y, Zhao Z, Xiang Z, Robakis NK, Shioi J, Suh J, Pasinetti GM: Cyclooxygenase (COX)-2 and COX-I potentiate beta-amyloid peptide generation through mechanisms that involve gamma-secretase activity. J Biol Chem 2003, 278(5 I):50970-50977.

52. Yan Q, Zhang J, Liu H, Babu-Khan S, Vassar R, Biere AL, Citron M, Landreth G: Anti-inflammatory drug therapy alters beta-amyloid processing and deposition in an animal model of Alzheimer's disease. J Neurosci 2003, 23(20):7504-7509.

53. Eriksen JL, Sagi SA, Smith TE, Weggen S, Das P, McLendon DC, Ozols $\mathrm{VV}$, Jessing $\mathrm{KW}$, Zavitz $\mathrm{KH}$, Koo EH, et al.: NSAIDs and enantiomers of flurbiprofen target gamma-secretase and lower Abeta 42 in vivo. J Clin Invest 2003, I I 2(3):440-449.

54. Weggen S, Eriksen JL, Sagi SA, Pietrzik CU, Ozols V, Fauq A, Golde $\mathrm{TE}$, Koo EH: Evidence that nonsteroidal anti-inflammatory drugs decrease amyloid beta 42 production by direct modulation of gamma-secretase activity. J Biol Chem 2003, 278(34):31831-31837.

55. Netzer WJ, Dou F, Cai D, Veach D, Jean S, Li Y, Bornmann WG, Clarkson B, Xu H, Greengard P: Gleevec inhibits beta-amyloid production but not Notch cleavage. Proc Natl Acad Sci USA 2003, I 00(2 I): I 2444- I 2449.

56. Milano J, McKay J, Dagenais C, Foster-Brown L, Pognan F, Gadient R, Jacobs RT, Zacco A, Greenberg B, Ciaccio PJ: Modulation of notch processing by gamma-secretase inhibitors causes intestinal goblet cell metaplasia and induction of genes known to specify gut secretory lineage differentiation. Toxicol Sci 2004, 82(I):34I-358.
57. Seiffert D, Bradley JD, Rominger CM, Rominger DH, Yang F, Meredith JE Jr, Wang Q, Roach AH, Thompson LA, Spitz SM, et al.: Presenilin$I$ and $\mathbf{- 2}$ are molecular targets for gamma-secretase inhibitors. J Biol Chem 2000, 275(44):34086-3409l.

58. Fraering PC, LaVoie MJ, Ye W, Ostaszewski BL, Kimberly WT, Selkoe DJ, Wolfe MS: Detergent-dependent dissociation of active gamma-secretase reveals an interaction between Pen-2 and PSI-NTF and offers a model for subunit organization within the complex. Biochemistry 2004, 43(2):323-333.

59. Morohashi $\mathrm{Y}, \mathrm{Kan} \mathrm{T}$, Tominari $\mathrm{Y}$, Fuwa H, Okamura $\mathrm{Y}$, Watanabe N, Sato C, Natsugari H, Fukuyama T, Iwatsubo T, et al.: C-terminal fragment of presenilin is the molecular target of a dipeptidic gamma-secretase-specific inhibitor DAPT (N-[N-(3,5-difluorophenacetyl)-L-alanyl]-S-phenylglycine t-butyl ester). J Biol Chem 2006, 28 I(2I): I4670-|4676.

60. Fraering PC, Ye W, LaVoie MJ, Ostaszewski BL, Selkoe DJ, Wolfe MS: gamma-Secretase substrate selectivity can be modulated directly via interaction with a nucleotide-binding site. J Biol Chem 2005, 280(5I):41987-4I996.

6I. Geling A, Steiner H, Willem M, Bally-Cuif L, Haass C: A gammasecretase inhibitor blocks Notch signaling in vivo and causes a severe neurogenic phenotype in zebrafish. EMBO Rep 2002, 3(7):688-694.

62. Jiang YJ, Brand M, Heisenberg CP, Beuchle D, Furutani-Seiki M, Kelsh RN, Warga RM, Granato M, Haffter P, Hammerschmidt $M$, et al.: Mutations affecting neurogenesis and brain morphology in the zebrafish, Danio rerio. Development 1996, I 23:205-2 I6.

63. van Eeden FJ, Granato M, Schach U, Brand M, Furutani-Seiki M, Haffter $P$, Hammerschmidt $M$, Heisenberg CP, Jiang $Y$ J, Kane DA, et al: Mutations affecting somite formation and patterning in the zebrafish, Danio rerio. Development 1996, I23:153-164.

64. Petit A, Pasini A, Alves Da Costa C, Ayral E, Hernandez JF, Dumanchin-Njock C, Phiel CJ, Marambaud P, Wilk S, Farzan M, et al.: JLK isocoumarin inhibitors: selective gamma-secretase inhibitors that do not interfere with notch pathway in vitro or in vivo. J Neurosci Res 2003, 74(3):370-377.

65. Esler WP, Kimberly W, Ostaszewski B, Ye W, Diehl T, Selkoe D, Wolfe MS: Activity dependent isolation of the presenilin-gsecretase complex reveals nicastrin and a $\mathbf{g}$ substrate. Proc Natl Acad Sci 2002, 99(5):2720-2725.

66. Campbell W, Wolfe M, Xia W: Assays for Amyloid Precursor Protein g-Secretase Activity. In Amyloid Precursor Protein, A Practical Approach Edited by: Xia W, Xu H. Boca Raton: CRC Press; 2005:51-68.

67. Ray WJ, Yao M, Nowotny P, Mumm J, Zhang W, Wu JY, Kopan R, Goate AM: Evidence for a physical interaction between presenilin and Notch. Proc Natl Acad Sci USA 1999, 96(6):3263-3268.

68. Zhang J, Ye W, Wang R, Wolfe MS, Greenberg BD, Selkoe DJ: Proteolysis of chimeric beta-amyloid precursor proteins containing the Notch transmembrane domain yields amyloid beta-like peptides. J Biol Chem 2002, 277(I 7): I5069-I5075.

69. Isoo N, Sato C, Miyashita H, Shinohara M, Takasugi N, Morohashi Y, Tsuji S, Tomita T, Iwatsubo T: Abeta42 overproduction associated with structural changes in the catalytic pore of gammasecretase: common effects of Pen-2 N-terminal elongation and fenofibrate. J Biol Chem 2007, 282(I 7): I 2388-12396.

70. Chen F, Hasegawa H, Schmitt-Ulms G, Kawarai T, Bohm C, Katayama $\mathrm{T}, \mathrm{Gu} Y$, Sanjo N, Glista M, Rogaeva E, et al.: TMP2 I is a presenilin complex component that modulates gamma-secretase but not epsilon-secretase activity. Nature 2006, 440(7088): | 208-| $2 \mid 2$.

7I. Best JD, Smith DW, Reilly MA, O'Donnell R, Lewis HD, Ellis S, Wilkie N, Rosahl TW, Laroque PA, Boussiquet-Leroux C, et al:: The novel gamma secretase inhibitor $\mathbf{N}$-[cis-4-[(4-chlorophenyl)sulfonyl]-4-(2,5-difluorophenyl)cyclohexyl]- I, I, I-trifl uoromethanesulfonamide (MRK-560) reduces amyloid plaque deposition without evidence of notch-related pathology in the Tg2576 mouse. J Pharmacol Exp Ther 2007, 320(2):552-558.

72. Lewis HD, Perez Revuelta BI, Nadin A, Neduvelil JG, Harrison T, Pollack SJ, Shearman MS: Catalytic site-directed gamma-secretase complex inhibitors do not discriminate pharmacologically between Notch S3 and beta-APP cleavages. Biochemistry 2003, 42(24):7580-7586.

73. Li YM, Xu M, Lai MT, Huang Q, Castro JL, DiMuzio-Mower J, Harrison T, Lellis C, Nadin A, Neduvelil JG, et al.: Photoactivated 
gamma-secretase inhibitors directed to the active site covalently label presenilin I. Nature 2000, 405(6787):689-694.

74. Kornilova AY, Bihel F, Das C, Wolfe MS: The initial substratebinding site of gamma-secretase is located on presenilin near the active site. Proc Natl Acad Sci USA 2005, 102(9):3230-3235.

75. Leimer U, Lun K, Romig H, Walter J, Grunberg J, Brand M, Haass C: Zebrafish (Danio rerio) Presenilin Promotes Aberrant Amyloid b-Peptide Production and Requires a Critical Aspartate Residue for Its Function in Amyloidogenesis. Biochem 1999, 38:13602-13609.

76. Groth C, Nornes S, McCarty R, Tamme R, Lardelli M: Identification of a second presenilin gene in zebrafish with similarity to the human Alzheimer's disease gene presenilin2. Dev Genes Evol 2002, 2 I 2:486-490.

77. Nornes S, Groth C, Camp E, Ey P, Lardelli M: Developmental control of Presenilin I expression, endoproteolysis, and interaction in zebrafish embryos. Exp Cell Res 2003, 289(I): I24-132.

78. Grimwood S, Hogg J, Jay MT, Lad AM, Lee V, Murray F, Peachey J, Townend T, Vithlani M, Beher D, et al.: Determination of guineapig cortical gamma-secretase activity ex vivo following the systemic administration of a gamma-secretase inhibitor. Neuropharmacology 2005, 48(7): I002-101I.

79. Dovey HF, John V, Anderson JP, Chen LZ, de Saint Andrieu P, Fang LY, Freedman SB, Folmer B, Goldbach E, Holsztynska EJ, et al.: Functional gamma-secretase inhibitors reduce beta-amyloid peptide levels in brain. J Neurochem 200I, 76(I): |73-18I.

80. Siemers ER, Dean RA, Friedrich S, Ferguson-Sells L, Gonzales C, Farlow MR, May PC: Safety, tolerability, and effects on plasma and cerebrospinal fluid amyloid-beta after inhibition of gammasecretase. Clin Neuropharmacol 2007, 30(6):3 17-325.

8I. Siemers ER, Quinn JF, Kaye J, Farlow MR, Porsteinsson A, Tariot P, Zoulnouni P, Galvin JE, Holtzman DM, Knopman DS, et al.: Effects of a gamma-secretase inhibitor in a randomized study of patients with Alzheimer disease. Neurology 2006, 66(4):602-604.

82. Fleisher AS, Raman R, Siemers ER, Becerra L, Clark CM, Dean RA, Farlow MR, Galvin JE, Peskind ER, Quinn JF, et al.: Phase 2 safety trial targeting amyloid beta production with a gamma-secretase inhibitor in Alzheimer disease. Arch Neurol 2008, 65(8): $1031-1038$.

83. Xia W, Xu H: Amyloid Precursor Protein, A Practical Approach. Boca Raton, FL.: CRC Press; 2004.

84. Johnson-Wood K, Lee M, Motter R, Hu K, Gordon G, Barbour R, Khan K, Gordon M, Tan H, Games D, et al.: Amyloid precursor protein processing and $\mathrm{A}$ beta42 deposition in a transgenic mouse model of Alzheimer disease. Proc Natl Acad Sci USA 1997, 94(4): I550-1555.

85. Ray W], Yao M, Mumm J, Schroeter E, Saftig P, Wolfe M, Selkoe D, Kopan R, Goate AM: Cell surface presenilin-I participates in the g-secretase-like cleavage of Notch. J Biol Chem 1999, 274:3680I-36807.

86. Berechid BE, Kitzmann M, Foltz DR, Roach AH, Seiffert D, Thompson LA, Olson RE, Bernstein A, Donoviel DB, Nye JS: Identification and characterization of presenilin-independent Notch signaling. J Biol Chem 2002, 277(1 0):8154-8I65.

87. Xia W, Zhang J, Perez R, Koo EH, Selkoe DJ: Interaction between amyloid precursor protein and presenilins in mammalian cells: implications for the pathogenesis of Alzheimer disease. Proc Natl Acad Sci USA 1997, 94( I5):8208-82। 3

88. Kimmel CB, Ballard WW, Kimmel SR, Ullmann B, Schilling TF: Stages of embryonic development of the zebrafish. Dev Dyn 1995, 203(3):253-310

89. Thisse C, Thisse B, Schilling TF, Postlethwait JH: Structure of the zebrafish snaill gene and its expression in wild-type, spadetail, and no tail mutant embryos. Development 1993, II9:1203-1215.

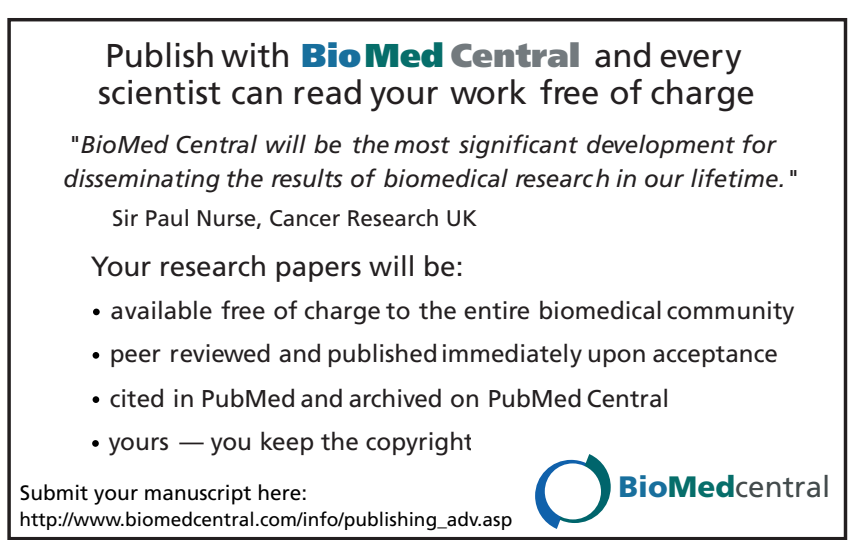

